\title{
The Model of Disaster Information Dissemination Based on Volunteer Communities: A Case Study of Volunteer Communities in Bandung Regency, West Java, Indonesia
}

\author{
Nuning Kurniasih*

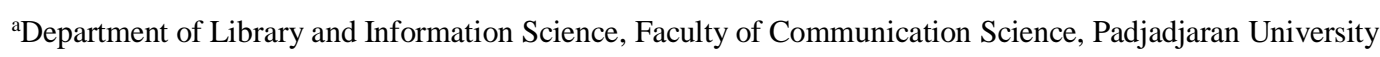 \\ Jl. Raya Bandung Sumedang KM. 21 Jatinangor Sumedang Indonesia \\ nuning.kurniasih@unpad.ac.id / nuningkurniasih@yahoo.com \\ Proceedings of the International Conference on Library and Information Science \\ Kyoto, Japan, 12-14 July 2016 \\ Pages: $285-313$ \\ Publisher: IBAC Taipe Taiwan
}

\begin{abstract}
This research aims to find a model of disaster information dissemination based on volunteer communities in Bandung Regency, West Java, Indonesia. In this research, data obtained from Focus Group Discussion (FGD) conducted by informants, in-depth interview with the experts related to this research, observation and literature review are analyzed. The sampling was done by purposive sample with criteria such as a person who (1) has been a volunteer disaster at least 1 year; (2) joins a volunteer community; (3) obtains a volunteer training (4) is active as disaster volunteer in the past year, conducting from five of volunteer communities, namely: TAGANA, UCS, PSM, SIBAT and DASI PENA. The total number of the informants is 13 people. Triangulation method is used by interviewing two of disaster practitioners who deal directly with disaster volunteer communities. The research results show (1) The person in charge for disaster information dissemination in Bandung Regency is Regional Disaster Management Agency (BPBD) through the Operations Control Center Manager (PUSDALOPS) and the process of information dissemination begins with the early warning which is delivered to the village and sub-district or to the disaster volunteer communities via radio, SMS Gateway, words of mouth, website, blog, Twitter and Facebook; (2) There are many volunteer communities in Bandung Regency, some of which is founded by government agencies, private sectors, political parties, professional communities, the public, etc.; (3) The supervising institutions of volunteer communities provides the training to the members to have knowledges and skills to be able to deal with the disasters, protect themselves and help the others; (4) The character of the people who have experience in disaster frequently in the environment tends to think that disasters is a normal occurrence and feel like already knows everything so they are passive in seeking of disaster information. The characteristics of community are also influenced by religion and belief, environmental, economic, social and cultural


factors as well as technological factors. (5) The role of the volunteer communities in the dissemination of disaster information is divided into three phases: pre-disaster, emergency response and post-disaster. The activities can be in the form of socialization, simulations and coaching for disasters, correcting the disaster disinformation, etc. (6) The volunteer communities coordinate with local community leaders/opinion leaders to make effective communication process with the public. (7) The direction of command/ coordination of disaster information dissemination based on volunteer communities started from the command of BPBD, then coordinated with the supervising institutions of volunteer communities, collaboration with opinion leaders and then prepare a good communication strategy in order to disseminate disaster information can be received by the public well. With good knowledge of the disaster, it is expected that the society becomes aware to the disaster, keeps the environment, protects themselves and helps families and the others, participating in disaster management and disaster risk reduction on pre-disaster, emergency response, and postdisaster (8) The model of disaster information dissemination is started from the policy of disaster management by appointing the person in charge for disaster information dissemination and coordinating with related parties, and then it is continued by determining the dissemination target, identifying the needs of disaster information, selecting and identifying the available information source and producing new information that has not been available yet but the people need it, composing module or disaster information package, arranging the message delivery strategy, choosing volunteer community as an information channel, coordinating with all of the parties in the field, executing the disaster information dissemination, collecting feedback, evaluating, compiling the report and recommendation from related parties as the material to make the policy of information dissemination better for the future.

Keyword: Information dissemination model, volunteer communities, disaster

\section{INTRODUCTION}

Bandung, a city in West Java, Indonesia, is widely known as the Paris van Java. The beauty of Bandung can be seen from the beautiful nature and mountains surround it so it looks like a basin. Nevertheless, the beautiful Bandung also has the potential of disasters, such as earthquakes, landslides, fires, social disasters, air pollution and floods. As an administrative area, Bandung is divided into two regions, namely the Bandung City and Bandung Regency. Bandung geographic region is like a big bowl that makes the water is stagnant and hard to recede then it leads this area as flood-prone area. In Bandung City, flood-prone areas cover the area through the rivers flows of Cipaku, 
Cikapundung, Cibeunying, Cipamokolan, and Cipadung. In Bandung Regency, Regional Disaster Management Agency (BPBD) of West Java reported the latest disaster that occurred in Bandung Regency was a flood (BPBD Provinsi Jawa Barat 2016). There are about 10 districts of 31 districts are affected by the floods from the Citarum River commonly. From all the regions in Bandung that affected by a flood, there are three sub-districts that are the most severely affected by floods, namely Dayeuh Kolot Sub-District, Baleendah Sub-district and Bojongsoang Sub-district.

Floods in these three districts have been going for decades routinely when the rainy season. There are several causes of flood in these three areas, such as:

1. Dayeuh Kolot, Baleendah and Bojongsoang Regional districts are the lowest area in Bandung area that is in the watershed of Citarum and creeks of Cikapundung.

2. Unplanned urban development, especially for the arrangement of the industry.

3. The people behavior who often littering and lack of temporary trash shelters create piles of garbage.

Thus the disaster can occur because of natural factors and human activities. The disaster, which happened because of natural factors, may be difficult to avoid and predictable, but disasters because of human activities can be avoided and they are predictable. We need to build awareness to avoid the behaviors that can destroy nature and create catastrophe. People need to get used to keeping the environment and make a good relationship with the nature. To raise the awareness, people need proper knowledge. For the above reason, dissemination of disaster information is critical.

Disasters inflict a risk. Disaster risk is a potential loss caused by disasters in a region within a certain time that can be death, injury, illness, threatened life, the loss of a sense of security, displacement, damage to or loss of property, and impaired activities of society (Bupati Bandung 2013). To reduce the risk of disaster, it takes an anticipatory act against these risks. People in the disaster areas like in Dayeuh Kolot, Baleendah and Bojongsoang sub-districts are expected to have better preparation to face the floods over the years so it can reduce the negative impacts of floods. Disaster preparedness can be realized with the participation of all parties, including government, private sector, volunteers and the general public in the face of disaster.

Participation of all elements of society in helping to overcome the impact of flooding in three flood-prone areas has already been done when the flood occurred. Unfortunately, the anticipatory action or pre-disaster actions to face the floods is getting less attention. Sometimes we heard there are people trapped in flooded areas and it might cause fatalities. For example, in the Dayeuh Kolot Sub-District there is a boy, 13 years old, died due to electric shock when the flood occurred and one man aged 40 years died dragged by the rapids at the beginning of March 2016 (Rahayu 2016), two of people trapped in the house were submerged due to Citarik rivers overflowing (Kantor SAR Bandung 2016), 3 of 
people was missing because they evacuate themselves to the building by the river and the building collapsed (OnlineBerita News 2016) etc. These cases are not expected, and it can be avoided by the vigilance of the public.

Disaster preparedness by the public can be started with structured and directional of dissemination of disaster information. In Bandung Regency, flood disaster management is under the coordination of the Regional Disaster Management Agency (BPBD) of Bandung regency. BPBD coordinates relevant agencies to disseminate disaster information in accordance with their respective role. The limited numbers of officials of government agencies have government agencies build a voluntary community / voluntary organizations that can help them reach out to the community. The existence of a voluntary communities/ voluntary organizations is currently more focusing on emergency response of a disaster.

The result of Nuning Kurniasih and Sukaesih's research mention that:

"Public health information behavior in flood-prone area in Baleendah Village, Andir Village, Dayeuh Kolot Village and Bojongsoang Village of Bandung Regency is passive. They will start to seek health information when they get sick. If they are well, the people are usually passive and the healthcare workers are usually active to give health information to the public. The dissemination of health information from a person to another is almost never occurred because they assume that they all already know" (Kurniasih and Sukaesih 2016).

Because of this passive characteristics of the society, more efforts from the government is required through their volunteers community / organization in order to become facilitators in spreading disaster information to reduce the disaster risk.

This research aims to find a model of disaster information dissemination through volunteer communities in Bandung Regency. With good knowledge about disaster, the community is expected to be aware to disaster, can maintain the environment, can protect themselves and help their families and others, participate in disaster management and reduce the disaster risks on pre-disaster, emergency response and post-disaster.

Increasing public awareness in anticipating disasters to reduce risk, disaster mitigation, disaster relief through increased community participation with the main target communities in disaster-prone areas are accordance with one of the missions of the Regional Disaster Management Agency (BPBD) as the disaster controller in Bandung Regency (BPBD Kabupaten Bandung 2011). When the model of disaster information dissemination based on volunteer communities is successfully applied, then the model of disaster information dissemination based on community can be developed.

\section{Research Questions}


To achieve the research objectives, this research seeks to answer the following research questions:

1. How is dissemination of disaster information in Bandung Regency currently going?

2. Which of volunteer communities that assist the disaster relief actively in Bandung Regency?

3. What kind of disaster knowledge and skills owned by members of volunteer communities in Bandung Regency?

4. How are the characteristics of society in disaster-prone areas in Bandung Regency?

5. How is the role of volunteer communities in disseminating disaster information in Bandung Regency?

6. How does the volunteer communities collaborate with the opinion leaders in the disseminating disaster information in Bandung Regency?

7. How is the direction of command/ coordination on disaster information dissemination based on Volunteer Communities in Bandung Regency?

8. How is the model of disaster information dissemination based on volunteer communities?

\section{Literature Review}

The International Federation of Red Cross and Red Crescent Societies (IFRC) defines a disaster as follows:

"A disaster is a sudden, calamitous event that seriously disrupts the functioning of a community or society and causes human, material, and economic or environmental losses that exceed the community's or society's ability to cope using its own resources" (The International Federation of Red Cross and Red Crescent Societies (IFRC) 2014).

Disaster, in the context of the local community, is understood as:

1. Disaster is surrounded by the idea of nature and God.

2. Disaster is defined as the social learning of human existence when in contact with nature.

3. Disaster is experienced as the strength of the new social and cultural formation (reproduction), because it lasts on social and values experiences.

(Puslitbang Aptel-SKDI 2009)

Disaster information includes information that can help people to prepare for a disaster, ranging from pre-disaster, during disaster and after disaster strikes. Disaster information needs to be conveyed to the public to build the awareness to disaster and reduce the risk of a disaster. 
Results of research of Ministry of Communication and Information Technology of Republic of Indonesia in 2009 showed that the program of dissemination of disaster information to reduce the risk of disaster in disaster-prone areas is still needed by the community who live in disaster-prone areas (Puslitbang Aptel-SKDI 2009).

Dhawan, defines the dissemination of information as follows:

"Information dissemination is a proactive information service designed to educate and inform focused groups of users on social, economic and educational issues, problems, and opportunities of interest to them. It requires systematic planning, collection, organization, and storage of information for its delivery to the target audience using different media and communication means" (Dhawan 20xx).

Because the information must be planned, we need to implement the steps in the dissemination of information such as identifying the needs, gathering data, analyzing data, producing and disseminating information.

The effectiveness of information dissemination is strongly influenced by factors both internal and external factors of providers and recipients of information. Internal factors include effectiveness measures, change in behavior, change in attitude, change in knowledge, cost and evaluation; and the external factors include cultural constraints, socio-economics factors, other sources, reinforcement of existing knowledge and research-based information. At the receiver side, the internal factors include perceived relevance of information, interaction with information and participant involvement in the strategy; and the external factors include recognition of need for new knowledge, information seeking style, awareness of information sources and willingness to change as a result of new information (Duggan and Banwell April 2004). Futhermore, Duggan and Banwell describe how the concepts link together as can be seen in Figure 1 below:

\section{Figure 1}

\section{Effective Dissemination}

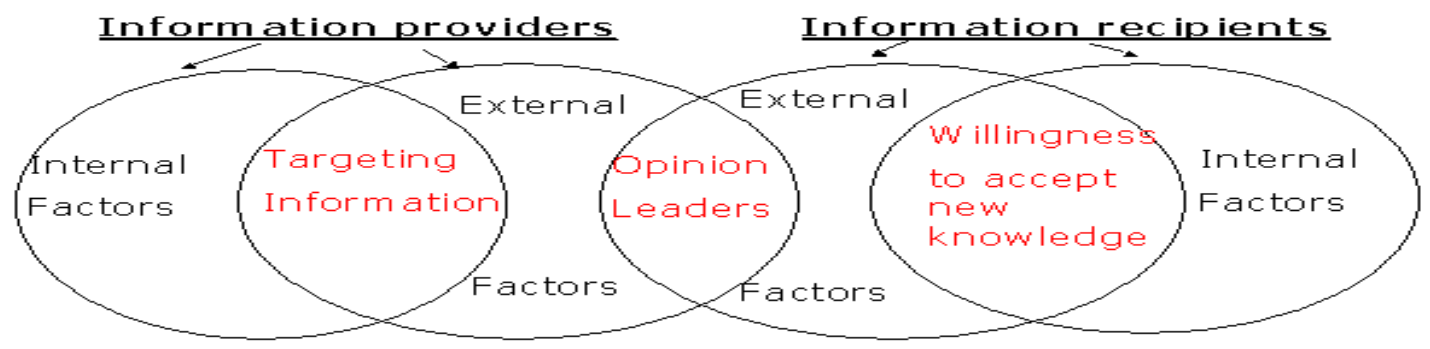

Source : (Duggan and Banwell April 2004)

From the diagram above, it can be seen that the information providers should be able to formulate who is the information target, while the recipient should have willingness to accept new knowledge. Between these two factors, there is a linking factor that is the opinion leader. 
There are several parties involved in management of information dissemination to local disaster. In the Figure 2, it can be seen that the parties involved in the dissemination of information include higher Officials, Local Officials, key person and the community by incorporating aspects of the timeline, expenditure, feasibility, flexibility, knowledge, equipment and personal in the message.

Figure 2

\section{Local Disaster Management Information Dissemination}

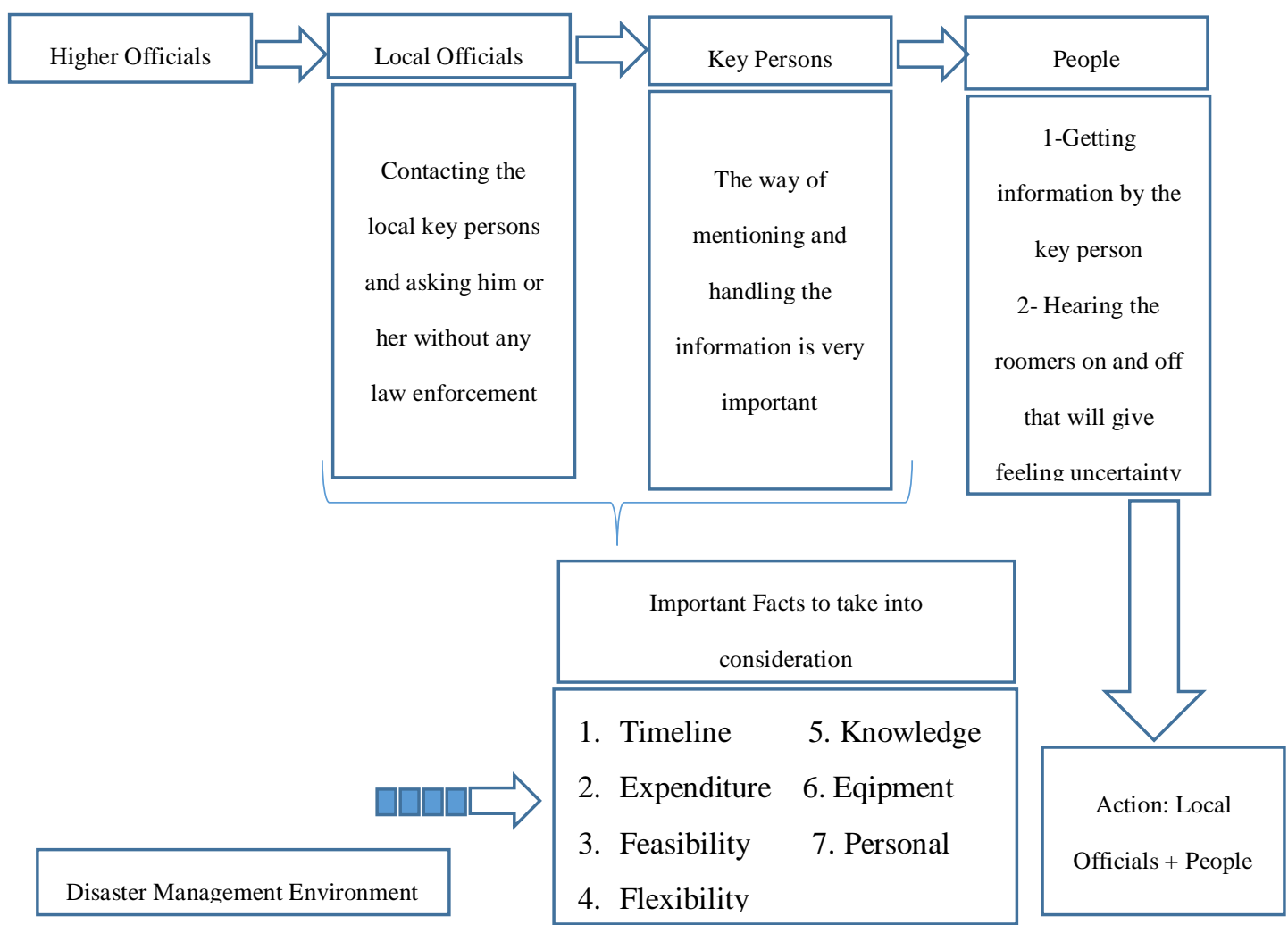

Source: (Mirzaei, Yapar and Mirtaheri 2008)

In the end, effective dissemination of disaster information will be occurred when the communication process is effective. According to Lasswell, there are three functions for communication (1) Surveillance of the environment (2) Correlation of components of society (3) Cultural transmission between generations. Lasswell also reveals that a convenient way to describe an act of communication is to answer the questions (1) Who (2) Says What (3) In Which Channel (4) To Whom (5) With what effect? (http://communicationtheory.org 2014).

Effective communication occurs when there is a common perception between the source and the recipient. Source credibility as proposed by Hovland and Weiss will determine acceptance of the message by the recipient of the message (Hovland and Weis 1951).

\section{Research Method}


The method used in this research is qualitative Case Study. According to Yin, "the distinctive need for case studies arises out of the desire to understand complex social phenomena" because "the case study method allows investigators to retain the holistic and meaningful characteristics of real-life events," (Yin 2003, 2). Furthermore Yin explained that a case study design should pay attention to (1) the study is to answer "how" and "why" questions; (2) Do not manipulate the behavior of those involved in the study; (3) covered contextual conditions; or (4) the boundaries between the phenomenon and context are not clear (Yin 2003).

There are three steps in case study planning, namely (1) Defining a case, (2) Selecting one of four types of case study design: single or multiple cases, holistic (single of unit of analysis) or embedded (multiple of units of analysis), (3) Using theory in design work (Yin 2003).

In this research, the case is a problem in the dissemination of disaster information in disaster-prone areas in Bandung Regency. Disaster in these regions repeated continuously. For example, there are three districts in Bandung, namely Dayeuh Kolot Sub-district, Bojongsoang Sub-district and Baleendah Sub-district which for decades has always been flooded during the rainy season. So, the case in this research is a single case.

At the flooding time, many volunteer communities help the community. The volunteer members are local residents close to the community and have received training that can maximize the role in disaster information dissemination. The unit of analysis consists of five of volunteer communities in Bandung Regency, embedded multiple of units of analysis.

The theory used in design work has been illustrated in the Literature Review, Figure 1 about Effective Dissemination. Figure 2 which depicts the Local Disaster Management Information Dissemination (Mirzaei, Yapar and Mirtaheri 2008), Communication Process of Laswell and Component Source of Credibility from Hovland and Weiss. In Figure 1 and 2 it is mentioned various components involved in the dissemination of disaster information along with the role and the necessary messages. However, in qualitative research, these theories are not as absolute as it can be developed in accordance with the field conditions. Researchers has been working to complete the formulation of research questions based on the contexts encountered in the field.

In this research, the data obtained from Focus Group Discussion (FGD) conducted by informants, in-depth interview with the experts related to this research, observation and literature review are analyzed. The sampling was done by purposive sampling. Informants in this study are selected based on several criteria, such as a person who (1) has been a volunteer disaster at least one year (2) joins the volunteer community (3) 
obtains the volunteer training (4) is active as disaster volunteer in the past year.

Based on the results of preliminary observations, there are many volunteer communities in Bandung Regency. Five samples of volunteer communities are which are active in the flood-prone area in Dayeuh Kolot Sub-district, Bojongsoang Sub-district and Baleendah Sub-district are gathered. They are:

1. Youth for Disaster-Preparedness (Taruna Siaga Bencana /TAGANA)

2. Volunteer of Prevention Alert Unit (Unit Cegah Siaga/ UCS)

3. Social Community Worker (Pekerja Sosial Masyarakat/ PSM)

4. Volunteer of Disaster Preparedness based on community (Relawan Siaga Bencana Berbasis Masyarakat/ SIBAT)

5. Youth Alert Disasters Preparedness (Pemuda Siaga Peduli Bencana/ DASI PENA) The total number of informants is 13 people.

Triangulation method is used by interviewing two of disaster practitioners who deal directly with disaster volunteer communities. They are from Regional Disaster Management Agency (BPBD) and Regional Agency for Social Services of Bandung Regency.

Data processing and analysis in this research is conducted through the stages as follows: (1) Organize the data (2) Coding of data (3) Analysis of the data (4) Interpretation of data.

\section{Research Results and Disscussion}

\section{Dissemination of Disaster Information in Bandung Regency}

The state's obligation in the dissemination of disaster information is stipulated in the Ministerial Regulation No. 1 of 2013 which reads: Providing accessibility is a service provided indirectly to the victims of natural disasters and / or people living in disasterprone-areas both in the pre, during and post-disaster include the provision of referral, a network of partnerships, facilities and information (Menteri Sosial Republik Indonesia 2013).

According to an interviewee from BPBD of Bandung Regency, the person in charge for the dissemination of disaster information in Bandung Regency is BPBD through the Operations Control Center Manager (PUSDALOPS) of BPBD of Bandung regency. The tasks of Manager of PUSDALOPS are:

a) Receive, record, process and analyze disaster data/ information.

b) Disseminate disaster information to the public or the government in Bandung Regency area.

c) To be the commander in post-emergency response of a disaster 
When there is no disaster occurred/ pre-disaster, the activities are commanded by BPBD Sub-Agency for Prevention and Preparedness. They assess the potential of disaster vulnerability. They will also relay the information from the Indonesian Agency for Meteorology, Climatology and Geophysics (BMKG) to the public through daily communication. Then, when the potential threat allegedly occurred in the area, BMKG or society will relay the information to BPBD either through radio, mail or SMS gateway. The society is the first response of BPBD. Furthermore BPBD will verify the information to the area and deliver the information to sub-district, village or volunteer communities by radio, mail or SMS gateway, website, blog, Twitter and Facebook.

For example, the information will be delivered by flood Operations Control Center (PUSDALOPS). Disaster information is started by the early warning where BPBD cooperate with BMKG and the National Institute of Aeronautics and Space (LAPAN) which conduct an assessment of rainfall. After processing data streams, Head of BPBD make an advice letter to the village and sub-district or volunteer communities. The advice was submitted via:

(a) Radio at frequency Band VHF 173,300 Mhz ,

(b) SMS Gateway with the number +6281214284944 ,

(c) Words of mouth,

(d) Internet : Website http://bpbd.jabarprov.go.id/ and

(e) Social media: Facebook BPBD Kab Bandung, Twitter account

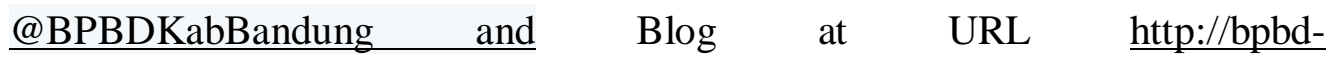
kabbandung.blogspot.co.id/

BPBD works with all the relevant institutions in dealing with floods corresponding Bandung Regency Regulation No. 23 of 2013 on the Division of Authority, Duties and Functions of the units of regional work in the Implementation of Disaster Management In Bandung Regency (Bupati Bandung 2013). For examples, here are the institutions that have the task to disseminate disaster information base on Regent Regulation No. 23 of 2013 On May 24, 2013:

a. BPBD has responsibility to develop Disaster Management Information System and Disaster-Sturdy Village (Desa Tangguh Bencana).

b. Regional General Hospitals of the Soreang, Majalaya and Cicalengka Subdistrict have responsibility to disseminate and make a simulation of disaster risk reduction in the hospital environment.

c. Regional Agency for Cooperatives, Small and Medium Enterprises, Trade and Industry, have responsibility to disseminate and make a simulation of disaster risk reduction in the economic environment and disaster-prone settlements.

d. Regional Agency for Education and Culture has responsibility to disseminate of disaster awareness for students and staff, as well as the facilitation of Disaster 
Preparedness Schools (Sekolah Siaga Bencana), etc.

\section{Volunteer Communities in Bandung Regency}

Based on the Regulation of the Minister of Social Services of Republic of Indonesia Number 1 of 2012 about Social Community Worker, Article 2, Social Community Workers (a) provide the opportunity for society to play a role in implementing social welfare widely (b) increase the people's awareness of the community in addressing social problems (Menteri Sosial Republik Indonesia 2012). According to an interviewee from BPBD, there are many volunteer communities in Bandung Regency, some of which are formed by government agencies, private sector, political parties, professional communities, the general public, etc. The volunteer communities are as follow:

a. Youth for Disaster-Preparedness (Taruna Siaga Bencana /TAGANA)

TAGANA is a volunteer community formed by the Ministry of Social Services of the Republic of Indonesia. One of their activities is Village of Disaster-Preparedness (Kampung Siaga Bencana/KSB).

b. Prevention and Preparedness Unit (Unit Cegah Siaga/ UCS)

UCS is a volunteer community formed by the Regional Disaster Management Agency (BPBD).

c. Social Community Worker (Pekerja Sosial Masyarakat/ PSM)

PSM is a volunteer community formed by the Ministry of Social Services of the Republic of Indonesia.

d. Disaster Preparedness based on Community (Relawan Siaga Bencana Berbasis Masyarakat/ SIBAT)

SIBAT is a volunteer community with the members are selected from the community cadre mover (kader penggerak masyarakat), established by Indonesian Red Cross (PMI) cooperated with the American Red Cross (AMCROSS). Team of SIBAT will run the FIRST program (Integrated Community Based Risk Reduction) that provides benefits to people in the neighborhood.

e. Youth Care Disasters Preparedness (Pemuda Siaga Peduli Bencana/ DASI PENA)

DASI PENA is a volunteer community, composed of Scout, nature lovers and other youth component formed by the Ministry of Health of Republic of Indonesia to support health efforts in disaster Management

, especially in the emergency response phase.

f. Srikandi Basarnas

Srikandi Basarnas consists of women in the Indonesian Agency for SAR (Basarnas).

g. Disaster-Preparedness Unit (Satuan Penanganan Bencana/Satgana)

Satgana is formed by the volunteers of the Indonesian Red Cross (PMI). 
h. Fast Action Response (Aksi Cepat Tanggap/ ACT)

ACT is a humanitarian organization that specializes in disaster Management and humanitarian disaster in an integrated (Integrated Disaster Management).

i. Indonesian Volunteers (Relawan Indonesia/Relindo)

Relindo is the new face of the Post of Disaster Relief (Pos Penanggulangan Bencana/ P2B) of Social Justice Party (Partai Keadilan Sosial/ PKS).

j. National Volunteer Committee and Volunteer of Alms House (Komite Relawan Nusantara/KRN and Relawan Rumah Zakat/RZ)

$\mathrm{KRN}$ is a foundation formed by Rumah Zakat (RZ) to overshadow the Volunteers of RZ.

k. Preparedness Volunteers (Relawan Siaga)

Relawan Siaga is a Non Governmental Organization (NGO) engaged Religious, Education, Empowerment, Greening, Humanities, Social Activity.

1. Save the Children

Save the Children is the leading global independent organization for children, such as education programs for inclusion and rehabilitation of children with disabilities, based on community. They collaborate with education authorities and labor offices district/ city and province.

m. Justice Scout (Pandu Keadilan)

Justice Scout is part of the Social Justice Party (Partai Keadilan Sosial/ PKS). One of their activities is helping people who the affected the disaster.

n. Volunteer of Disaster Management Agency (Relawan Badan Penanggulangan Bencana/ Baguna).

Baguna are volunteer community formed by the Indonesian Democratic Party of Struggle (Partai Perjuangan Indonesia Perjiangan/PDIP).

And many more.

In this study there are five of volunteer communities selected as object of research, namely TAGANA, UCS, KSB, PSM, SIBAT and DASI PENA.

From the results of the Forum Group Discussion (FGD) with the informants of research, it is known that they join a volunteer community voluntarily. For the volunteers, volunteering is a calling from the soul. Their motivation is just want to do good deeds. They do not expect compensation in the form of money. They only want to transfer their knowledge to do good deeds to others and hope to get reward from God. As we know that the Indonesian people are very religious, so the reason to live with the way of religion becomes a very important thing.

There is no salary in cash for the volunteers but they say they get Sajuta Honda (Honda is a brand and sajuta means one million). It is a humor to show that they enjoyed their role as a volunteer. Honda sajuta is Sundanese words which stands for Incentive from 
God (Honor dari Allah), Patience (Sabar), Honesty (Jujur) and trusting in God's plan (Tawakal).

For the volunteer communities that set up by government agencies such as TAGANA, UCS, PSM, SIBAT and DASI PENA, the recruitment process is usually started with a request from a supervising institution of the volunteer community to the sub-districts and villages and announced to the citizens. Then sub-districts send people who signed up to be a volunteer. To be a volunteer, they need to make a commitment to do these things for humanity and willing to work without salary. So far there are volunteers who are active and inactive. The inactive volunteers are usually they have an activity or work outside the district of Bandung Regency.

An interviewee of BPBD said that members of volunteer communities consist of diverse educational background, profession, age, socioeconomic status, etc. Meanwhile, according to informants of TAGANA, sometimes the people who joined TAGANA are jobless but because they shown the good works in TAGANA then they got a job. For example, informants of this research were jobless at the beginning, and then they got a job as Police Unit of Civil Service (SATPOL PP) or become an administrative employee in the village office or sub-district office. There are also people who have their own business before joined TAGANA like some of the informants of this research. After joining TAGANA, they get a new link for their business so their businesses become bigger. So, through a volunteer community, a volunteer can build a networking to develop their career or business. For TAGANA, the age is at most 45 years old. If there are more than 45 years old, they join the Legion TAGANA.

\section{Disaster Knowledge and Skills of Members of Volunteer Communities}

Dissemination of disaster information conveyed through the communication process. In the communication process, the credibility of the source is very important. Hovland and Weis said that the credibility of the source consists of expertise and trustworthiness, where that high credibility sources produced more attitude change than low credibility sources (Hovland and Weis 1951). Expertise of sources can be built through the appropriate knowledge and skills, while trustworthiness built on their gait or performance in the community. To build trustworthiness, volunteer community can involve the local leaders or opinion leaders in a community.

When a person is selected as a volunteer member, a volunteer will get training from the supervising institution. The training is usually given step by step depending on their basic capabilities and equitable of training participation among volunteers. Frequency, duration and training materials depend on the institutions. Disaster knowledge and skills is necessary so that volunteers can protect themselves and help people who affected by the disaster. 


\subsection{Training for Volunteers of TAGANA}

According to an interviewee from Social Agency of Bandung Regency, TAGANA is one of the best volunteer communities in Indonesia. There are currently 200 members of TAGANA in Bandung Regency. From the number of 200, there are 130 active members. Members of TAGANA join training organized by the Social Agency in stages, which are:

a. Basic of social guidance for novice TAGANA (TAGANA Muda)

b. Stabilization of capacity building for intermediary TAGANA (TAGANA Madya). The learning materials include 12 of skills: (1) Team of Rapid Response/ TRC (2) Concept of Nationalism (3) Introduction to Public Kitchen Fields (4) Shelter Management (5) Emergency Response (6) Mechanical Extinction of Fire (7) Basic Knowledge of Marching (8) Logistics Management (9) TAGANA philosophy (10) Disaster Management (11) Mental and Physical Assist (12) Psychosocial

c. Training is divided into clusters, depending on the member skill for Expert TAGANA (TAGANA Utama). Training provided to TAGANA is semi-military.

\subsection{Training for Volunteers of UCS}

An interviewee of BPBD describes there are currently around 400 volunteers joining UCS. Volunteers, who do not have basic skills, are given the training, while volunteers who have been trained would not be trained again. Materials provided during the training include:
a. Disaster material
b. Preparedness material
c. Standard Emergency Management System (SMKD)
d. Fields Control Command System
e. Disaster Simulation, etc.

\subsection{Training for Volunteers of PSM}

PSM has a role as a social worker and is expected to be an agent of the government in disseminating the social welfare development program along with community problems. The informants said that the materials that received by volunteers support the development and social services for people with social problems in the region, including in the effect of a disaster.

\subsection{Training for Volunteers of SIBAT}


In Bandung regency, SIBAT began in 2015. The volunteers were selected in this SIBAT is not really new volunteers. They have many years volunteering in the region. Nevertheless, they are still training with the materials, such as:

a. Handling of disaster victims.

b. Triage, which is a grouping of victims / patients based on the level of the problem and speed of treatment.

c. Mitigation measures

d. Emergency command system in the community

e. SAR

After the training, volunteers are expected to be able to increase participation and awareness in anticipating and responding to a disaster.

\subsection{DASI PENA}

The training materials provided by the Ministry of Health to volunteers DASI PENA, include:

a. The basics of disaster management

b. Standard of health services

c. The initial assessment of disaster victims

d. Triage on disaster victims

e. The steps to help injured victim

f. Emergency rescue and stabilization of victims

g. Basic Cardilac Life Support (BCLS)

From all of all training provided by each supervising institutions, basically all volunteers have the knowledge and skills to be able to deal with disasters, protect and help the family and others.

\section{The Characteristics of Community in Disaster-Prone Areas in Bandung Regency}

To be able to convey the message effectively, the sender of the message needs to understand the characteristics of the message recipient. The sender of the message in this case is expected as the volunteer who joined a volunteer community and the recipient is the people in Bandung Regency, especially the people in disaster-prone areas. The volunteers who joined in the volunteer community are usually local people, so they can deal with the public directly and intensively. Thus the volunteers would not be too difficult to understand their audience characteristics.

For disaster-prone communities in Bandung regency, such as in Dayeuhkolot Subdistrict, Baleendah Sub-district and Bojongsoang Sub-district, the flood has been regarded as an annual agenda in the rainy season. As the results, the people there assume 
everything has been known and they are passive in seeking disaster information. Some informants assess that sometimes when a disaster occurs, people become spoiled, and they want to be served and they did not help the volunteer's tasks. Due to these conditions, the government or volunteer communities should be pro-active in the dissemination of disaster information and mobilize community to participate in disaster management.

Here are several factors that affect to the characteristics of the community, namely:

a. Religion and Belief Factors.

As mentioned in the previous section, Indonesian people including people in Bandung Regency are deeply religious society, so the understanding of the religion of the people is the main thing to understand.

b. Environmental Factors

Most communities in flood-prone areas in Bandung Regency has been settled for a long time in the region for generations, so that whatever happens there is hard to leave the place, although it provided a new form of flats by the government.

c. The Economic Factors

Some people in flood-prone areas in Bandung Regency expressed their interest to move to another place safer than current place but they cannot sell the house because it is located in disaster-prone areas. Even if there is a bid their home, usually the price is very cheap, so they opted to stay, especially for those who have jobs in the area.

d. Social and Cultural Factors

The community was comfortable with the their social and cultural environments.

e. Aspects of Technology

Although BPBD have used a variety of media, such as radio, SMS gateway, Website, Blogs, Social Media, Leaflets and Brochures to disseminate disaster information, but not all people can access the information. This is because there is still a gap of ownership and skills in the use of technology in society.

Understanding of the characteristics of the community is expected to become the basis for the volunteers in framing strategies or models of disaster information dissemination in Bandung Regency.

\section{The Role of Volunteer Communities in Dissemination of Disaster Information} Regional Decree No. 23 of 2013 reveals that the scope of disaster mitigation encompasses three stages:

a. Pre-disaster stage. Pre-disaster mitigation covers the effort to create the disaster that situation not to occur and that the disaster situation is detected. 
b. Emergency stage. Disaster mitigation in emergency stage covers: quick analysis of location, damage and resources; determination of emergency status; rescue and evacuation of the victims; fulfillment of basic needs; Reviews those who protection for the vulnerable; quick recovery of vital infrastructure; and the final step implementation of emergency stage.

c. Post-disaster stage. It covers rehabilitation and reconstruction.

(Bupati Bandung 2013)

Dissemination of disaster information on each stages are described in Appendix of Bandung Regent Regulation No. 23 of 2013 dated 24 May 2013. Based on literature review, researcher defines the role that can be implemented by the Volunteers Communities as:

In pre-disaster, volunteer communities can participate in the following activities:

1. Socialization and simulation with the theme:

a. Disaster risk reduction.

b. Environmental protection, such as the conservation and protection of forests, reduction of waste and pollution, urban planning based on environmental impact assessment and other natural resources.

c. Regional Regulation on Natural Disaster Areas.

d. Disaster management.

e. Signage of disasters-prone area and early warning systems.

2. Guidance or assistance for:

a. Conservation and protection of natural resources, including forests.

b. Controlling waste, pollution, urban planning based on environmental assessment strategic, environmental impact control with the law, conservation of natural resources and pollution.

c. Maintenance of infrastructure for public protection for disaster management, including the maintenance of communications equipment supporting disaster management plan, infrastructure for disaster needs and protecting cultural heritage buildings.

When a potential disaster detected, volunteer communities can play a role in

a. Counseling, training and simulation of emergency response.

b. Dissemination of information to potential and disaster warning.

In emergency response, volunteer communities can play a role in the delivery of the Assignment of Task Force Quick Reaction of information, evacuation and placement safe location.

In rehabilitation step, the role of volunteer communities is about the facilitation of information of infrastructure repair and replacement of the missing letters.

In reconstruction step, the roles that can be performed by volunteer communities are 
a. Community assistance through post-disaster skills training in order to the impact of disasters for independent entrepreneur and motivational enhancement training.

b. Reducing the information confusion in the context of disaster management.

Volunteer Communities have participated in the three-steps of disaster management. Their roles are currently more active in Emergency Response. Dissemination of disaster information in pre-disaster, actually has been done by volunteers to socialize the things that can cause man-made disasters, such appeals to do not throw garbage carelessly or always cleaning the ditches. In addition to that, the supervising institutions of volunteer communities such as BPBD, Regional Social Services Agency, Regional Public Health Agency, and others need to provide additional material so that volunteers can disseminate disaster information to the public optimally.

For the implementation, as has been mentioned before that disaster management, including dissemination of disaster information in Bandung Regency entirely under BPBD coordination. It means that there is only one command for disaster management in Bandung Regency, from BPBD. The coordination of dissemination of disaster information will be done very well if supported by the Disaster Information System, Standard Operating Procedure, Modules of Disaster Information Dissemination and the cooperation among information and communication network are well.

\section{Collaboration with the Opinion Leaders in the Dissemination of Disaster Information in Bandung Regency}

Dissemination of disaster information is not a new thing for a part of volunteer communities in Bandung Regency. However, the delivery of new messages by the Volunteer Communities as part of the optimization of the role of volunteers who is close with the community can be regarded as something new. According to Rogers, there are four factors that influence the decision process of innovation, namely:

a. Social Culture, a social structure in society. For example, the Regent is a post for the head of a Regency and BPBD is the controller coordinator of regional disaster management.

b. Norm System, a norm or a value that is embraced by the people, including norms or decency of the volunteer communities by the public perception to disseminate disaster information. For example, the norm system that used in Bandung area (Sundanese) is "silih asah, silih asih, silih asuh" which means mutual learning, mutual caring and mutual loving.

c. Change Agent, people who are considered as carriers of renewal in the neighborhood, so usually they are public figures, religious leaders, teachers, etc. 
d. Opinion leaders, composed of people who govern in a society. Usually they are the community leaders. The community leaders usually are the role models for society, they obeyed and imitated so it is easier to persuade the public. Bring community leaders in volunteer communities activities are very important in order to be accepted by the public.

Based on observation, the people that can be the opinion leader in disaster-prone areas in Bandung Regency are:

1. Government officials, such as the Regent, Head of Sub-district, Headman / Head of Village and staffs.

2. Religious Figures.

3. Doctor / Midwife Village / local health center officer.

4. Teacher

5. Cultural leaders / elders.

6 . Key person in a social organization.

The volunteer communities coordinate with local community leaders/opinion leaders such as government officials, religious figures, doctor, midwife village, local health center officer, teacher, cultural leaders/ elders, key person in a social organization, etc. to make effective communication process with the public.

\section{The Direction of Command/Coordination in Disaster Information Dissemination in Bandung Regency}

The process of communication on disaster information dissemination based on Volunteer Communities as we can see in Figure 3 shows that the dissemination of disaster information in Bandung Regency has only one command that is from BPBD. BPBD will coordinate with the Forum of Plan of Disaster Management Implementation (RPB) and other related institutions to formulate what kind of the disaster information should be conveyed to the public. This would go well if it is supported by Policy, Disaster Information System, Standard Operating Procedure, Command System and Modules of Dissemination of Disaster.

The supervising institution of volunteer communities provides a coaching so that their volunteers can deliver disaster information properly. There is two ways to persuade the recipient of the message. Firstly, persuasion based on content and logic of the message, secondly, persuasion based on non message factors such as attractiveness, credibility, emotion (Weiten, Dunn and Hammer 2012). Volunteer communities can use both. They have knowledge and skills as source of message/ content and they also build a good relationship with local community leaders/opinion leaders as non message factors. The supervising institutions and volunteer communities coordinate with local community leaders/opinion leaders to make effective communication process with 
the public.

Volunteer Communities prepare a communication strategy for dissemination of disaster information, including source credibility, approach method, content, media, timeline, etc. Then the people in the community will give their feedback to volunteer communities. In addition, volunteer communities also need to coordinate with the school or educational institutions, while BPBD is cooperating with mass media and other parties related. 
Figure 3

\section{The Command Direction/Coordination on Disaster Information Dissemination base on Volunteer Communities in Bandung Regency, West Java, Indonesia by Nuning Kurniasih}

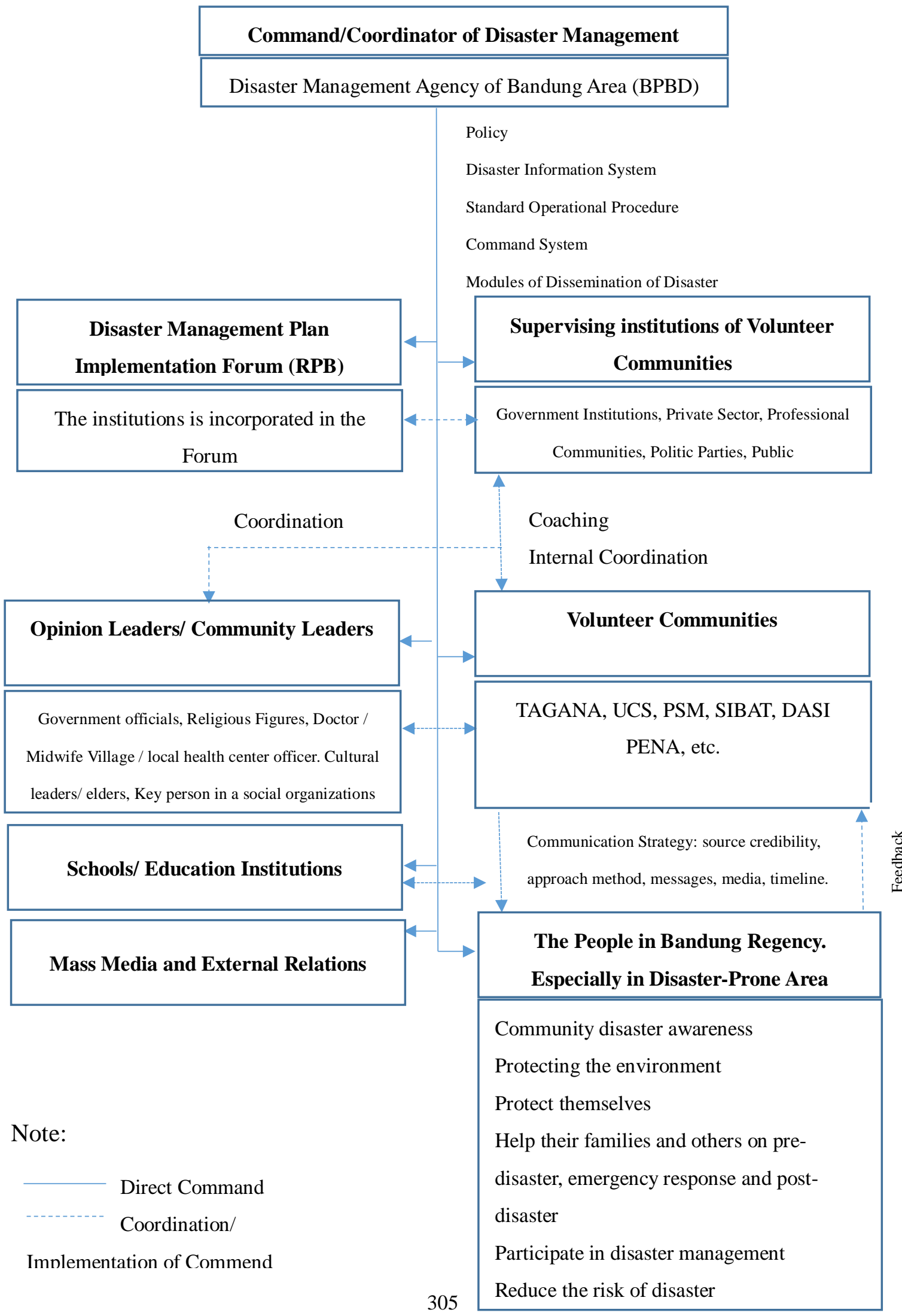


Effective dissemination of disaster information is expected to achieve community disaster awareness, the environment protection, self-survival ability, support of their families and others, participation in disaster management and the decline of the risk of disaster on pre-disaster, emergency response and post-disaster.

\section{The Model of Disaster Information Dissemination Base on Volunteer Communities}

The Model of Disaster Information Dissemination based on Volunteer Communities can be described as we see in The Figure 4.

From Figure 4, we can see that the model of disaster information dissemination is started from the policy of disaster management which covers the appointment of the person in charge and the coordination of disaster information dissemination with related parties. Then, the disaster target information is determined such as to improve the knowledge and skills, change the perception, change the behavior, etc. and also an identification of public needs of disaster information. The public needs in disaster information are identified through the available information identification and it is accordance with the public needs of disaster information.

Other required information productions are conducted after the process of selecting and analyzing of the available disaster information sources. Then, the local people create the modules or the disaster information packages in various media that are reachable. After the modules or the information packages are available, the disaster message/information delivery strategy is analyzed, for example, by understanding the characteristics of the local people. There are a lot of information dissemination channel, one of which that is considered effective is through the volunteer community, because usually the volunteer comes from the local community who lives near them and has understood the characteristics of the local people. The volunteers then are given some training so they can deliver the disaster information effectively.

After the volunteers are ready with their knowledge and skill, the volunteers are coordinating with related parties in the field: the village officials, public figures/opinion leader, local education institution, etc. After the situation is conducive, the information dissemination activity is executed by considering the source credibility, the message recipient characteristic, the approaching method of message recipient, the content, media, time and place of message delivery. After the disaster information dissemination is carried out, it is important to know the feedback of the message recipient as the evaluation material for the activity target whether is successful or failed. Finally, the volunteers give the activity report and recommendation for the next activity to the supervising institution. This report and recommendation are hoped to add some suggestions to the policy of information dissemination forward. 
Figure 4

\section{The Model of Disaster Information Dissemination \\ Base on Volunteer Communities \\ By Nuning Kurniasih}

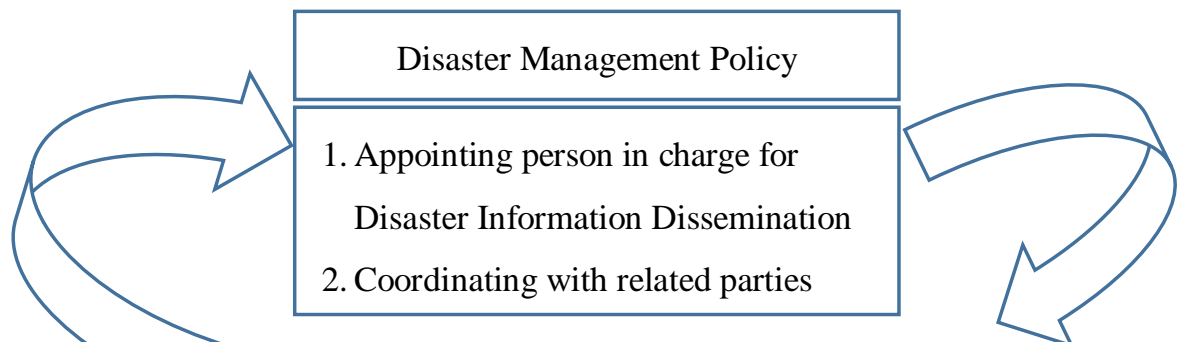

Deciding the Disaster Dissemination Target:

Compiling reports and recommendations

to the supervising institution

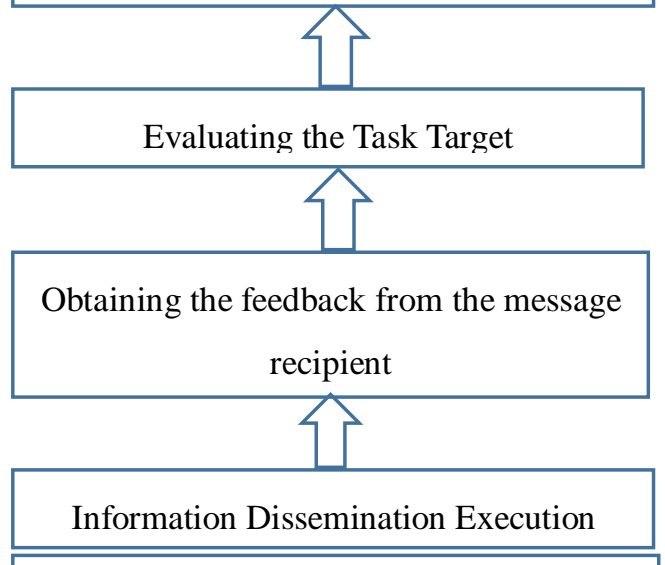

By considering: source credibility, the people's characteristics, approaching method to the recipient, content, media, time and place of message delivery.

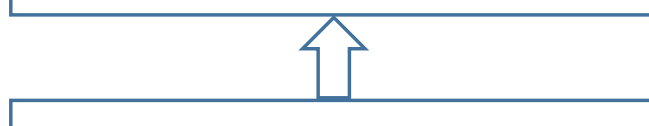

Coordinating with all related parties in the field: village officials, public

figure/opinion leader, schools, etc.

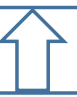

Choosing communication channel for information dissemination, such as through Volunteer Community improve the knowledge\&skills, change the perception, change the behavior, etc.

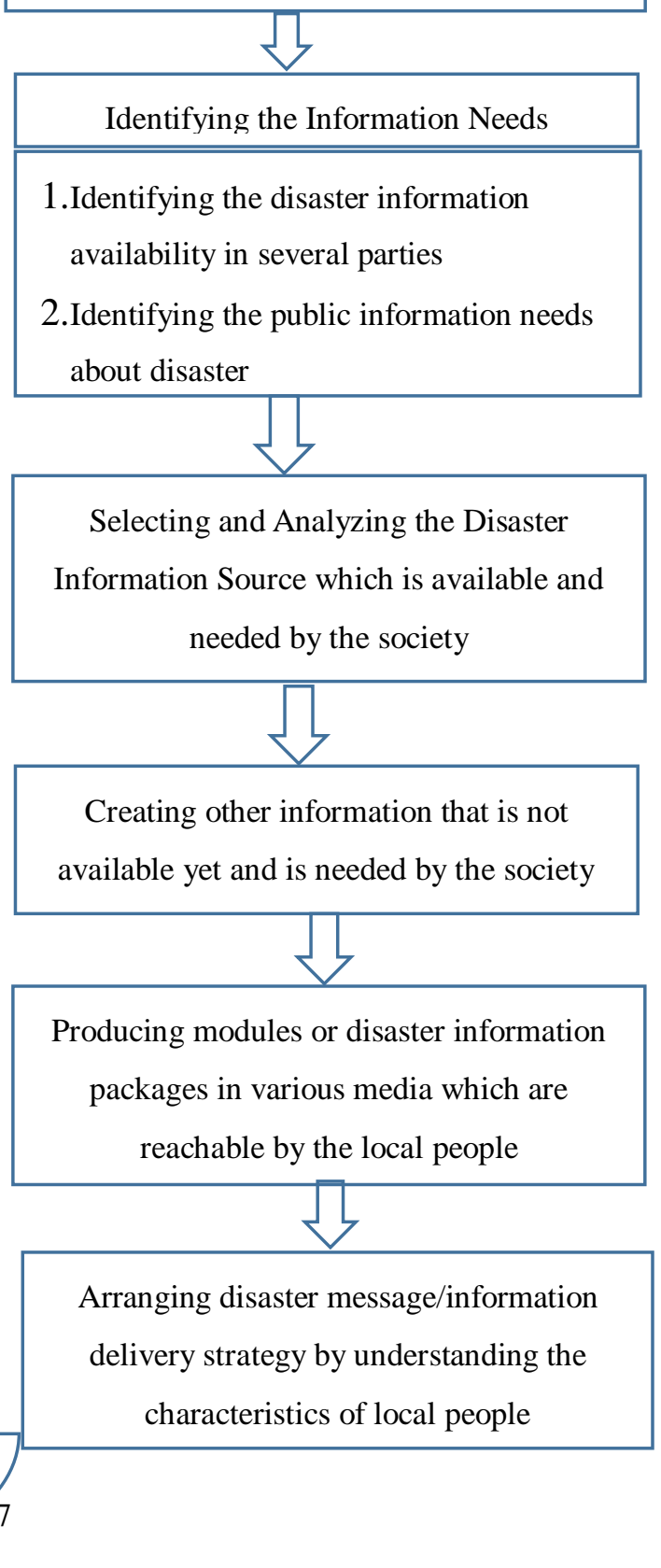




\section{Conclusions}

1. The person in charge for disaster information dissemination in Bandung Regency is a Regional Disaster Management Agency (BPBD) through the Operations Control Center Manager (PUSDALOPS). Information dissemination begins with the early warning which deliver to the village and sub-district or to the disaster volunteer communities, via radio, SMS Gateway, words of mouth, blog, Twitter and Facebook.

2. There are many volunteer communities in Bandung Regency, some of which are formed by government agencies, private sector, political parties, professional communities, the public, etc.

3. The supervising institution of volunteer communities provides the training to the members to have knowledge and skills to be able to deal with the disasters, protect and help the others.

4. The character of the people who have experience in disaster frequently in the environment tends to think that disasters are normal occurrences, and they feel like they already know everything so they are passive in seeking of disaster information. Sometimes when a disaster occurs, people become spoiled, want to be served and do not participate to help a volunteer tasks. This characteristics of community are also influenced by religion and belief, environmental factors, economic factors, social and cultural factors as well as technological factors.

5. The role of the volunteer communities in the dissemination of disaster information is divided into three phases: pre-disaster, emergency response and post-disaster. The activities can be in the form of socialization, simulations and coaching for disasters, correcting the disaster disinformation, etc.

6. The volunteer communities coordinate with local community leaders/opinion leaders to make effective communication process with the public.

7. The command direction/coordination of disaster information dissemination based on volunteer communities is started from the command of BPBD, then coordinated with the supervising institution, collaborated with opinion leaders and then prepare a good communication strategy in order to disseminate disaster information that can be received by the public well. With good knowledge of the disaster, it is expected that the society becomes aware to the disaster, keeps the environment, protects and helps the others on pre-disaster, emergency response, and post-disaster, participating in disaster management and disaster risk reduction.

8. The model of disaster information dissemination is started from the policy of disaster management by appointing the person in charge for information dissemination and coordinating with related parties, and then it is continued by 
determining the dissemination target, identifying the needs of disaster information, selecting and identifying the available information source and producing new information that has not been available yet but the people need it, composing module or disaster information package, arranging the message delivery strategy, choosing volunteer community as an information channel, coordinating with all of the parties in the field, executing the disaster information dissemination, collecting feedback, evaluating, compiling the report and recommendation from related parties as the material to make the policy of information dissemination better for the future.

\section{References}

Baškarada, Saša. 2014. "Qualitative Case Study Guidelines." The Qualitative Report Volume 19, How To Article 24, 1-18.

Baxter, Pamela, and Susan Jack. 2008. "Qualitative Case Study Methodology: Study Design and Implementation for Novice Researchers ." The Qualitative Report Volume 13 Number 4 December 544-559.

BPBD Kabupaten Bandung. 2011. Rencana Strategis BPBD Kabupaten Bandung 20112015 . Rencana Strategis BPBD Kabupaten Bandung 2011-2015 , Bandung: BPBD. Accessed April 30, 2016. http://www.bandungkab.go.id/uploads/BAB_IV_VISI_MISI,_TUJUAN.pdf.

BPBD Provinsi Jawa Barat. 2016. "Data Terkini Laporan Kejadian Bencana Per Jenis Bencana Tahun 2016." BPBD Jawa Barat. March 14. Accessed April 30, 2016. http://bpbd.jabarprov.go.id/.

Bupati Bandung. 2013. " Penyelenggaraan Penanggulangan Bencana di Kabupaten Bandung." Peraturan Bupati Kabupaten Bandung No. 2 Tahun 2013. Soreang: Pemda Kabupaten Bandung, January 2.

—. 2013. "Pembagian Kewenangan, Tugas, dan Fungsi Satuan Kerja Perangkat Daerah dalam Penyelengaraan Penanggulangan Bencana Di Kabupaten Bandung." Peraturan Bupati Kabupaten Bandung Nomor 23 Tahun 2013. Soreang: Pemda Kabupaten Bandung, Mei 24.

Coppola, Damon P. 2011. Introduction to International Disaster Management 2nd Ed. Burlington: Butterworth-Heinemann, Elsavier.

Departemen Komunikasi dan Informasi Republik Indonesia. 2009. " Laporan Akhir Studi Efektivitas Diseminasi Informasi Pengurangan Resiko Bencana di Daerah Rawan Bencana Puslitbang Aptel Skdibadan Penelitian dan Pengembangan SDM Departemen Komunikasi dan Informatika Tahun 2009." Research Report. Jakarta: Depkominfo RI, November.

Dhawan, S.M. 20xx. "Basics of Information Dissimination." In Learning Package on 
Participatory Adult Learning, Documentation and Information Networking (PALDIN) : Documentation, Dissemination and Networking - Course 02, by Group of Adult Education School of Social Sciences Jawaharlal Nehru University, 46-58. New Delhi : Group of Adult Education School of Social Sciences Jawaharlal Nehru University.

Duggan, Fiona, and Linda Banwell. April 2004. "Constructing a model of effective information dissemination in a crisis." Information Research Vol. 9 No.3 Paper 178 Available at http://InformationR.net/ir/9-3/paper178.html.

Hovland, Carl I., and Walter Weis. 1951. "The inXuence of Source Credibility on Communication eVectiveness." Public Opinion Quarterly, 15 635-650.

http://communicationtheory.org. 2014. Lasswell's model. July 16. Accessed April 30, 2016. http://communicationtheory.org/lasswells-model/.

Kantor SAR Bandung. 2016. Twitter Kantor Basarnas Bandung. Bandung, April 17. Kantor SAR Bandung. 2016. Twitter Kantor SAR Bandung. BAndung, February 27.

Kurniasih, Nuning, and Sukaesih. 2016. "Public Health Information Behavior at FloodProne Area In Bandung Regency: A Case Study in Baleendah Village, Andir Village, Bojongsoang Village and Dayeuh Kolot Village." International Conference on Science Mapping 20-21 April. Jogjakarta: Universitas Gadjah Mada.

Lasswell, Harold Dwight, and L. Bryson. 1948. The Structure and Function of Communication in Society. The Communication of Ideas. New York: Lasswell, Harold (1948). Bryson, L., ed. The Structure and Function of CoInstitute for Religious and Social Studies.

Menteri Sosial Republik Indonesia. 2013. "Bantuan Sosial bagi Korban Bencana. Jakarta: Departemen Sosial." "Permen No.1 Tahun 2013. Jakarta: Departemen Sosial, January 7.

—. 2012. "Pekerja Sosial Masyarakat." Peraturan Menteri Sosial Republik Indonesia No. 1 Tahun 2012. Jakarta : Kementerian Sosial Republik Indonesia, January 19.

—. 2013. "Permen No. 1 Tahun 2013 tentang Bantuan Sosial bagi Korban Bencana." Peraturan Menteri (Permen). Jakarta: Departemen Sosial Republik Indonesia, January 07. Menteri Sosial Republik Indonesia. 2013. "Permen No.1http://www.kemenpppa.go.id/jdih/peraturan/nspk-permensos-01-2013bantuan-sosial-korban-.

Mirzaei, Hamid Reza, Bijan Yapar, and Maisam Mirtaheri. 2008. "The Lessons Learnt from "Gonu Tropical Cyclone" ." Scientific Figure on ResearchGate. April. Accessed April 30, 2016. The Lessons Learnt from "Gonu Tropical Cyclone" Shttps://www.researchgate.net/267689360_fig1_Fig-1-Local-disaster- 
management-information-dissemination.

OnlineBerita News. 2016. POLITIK Nestapa Banjir Kabupaten Bandung. March 14. Accessed March 30, 2016. http://www.onlineberita.com/nestapa-banjirkabupaten-bandung.html.

Puslitbang Aptel-SKDI. 2009. Diseminasi Informasi Pengurangan Resiko Bencana pada Daerah Rawan Bencana. Jakarta: Badan Penelitian dan Pengembangan Depkominfo RI.

Rahayu, Juwita Trisna. 2016. Dua orang tewas dan 24.000 jiwa terdampak banjir Bandung. March 13. Accessed March 30, 2016. http://www.antaranews.com/549782.

Rogers, Everett M. 2003. Diffusion of Innovation Ed.5rd. New York: The Free Press.

The International Federation of Red Cross and Red Crescent Societies (IFRC) . 2014. Whai is a Disasters. April 08. Accessed April 30, 2016. http://www.ifrc.org/en/what-we-do/disaster-management/about-disasters/whatis-a-disaster/.

Weiten, Wayne, Dana S. Dunn, and Elizabeth Yost Hammer. 2012. Psychology Applied to Modern Life: Adjustment in the 21st Century ed.10th. Belmont: Wadsworth Cengage Learning.

Yin, Robert K. 2003. Case study research: Design and methods (3rd ed.). Thousand Oaks, CA: Sage. 


\section{APPENDIX}

BMKG (Badan Meteorologi, Klimatologi dan Geofisika/ Indonesian Agency for Meteorology, Climatology and Geophysics (BMKG)

$\mathrm{BMKG}$ is an Indonesian non-departmental government agency for Meteorology, Climatology and Geophysics.

BPBD (Badan Penanggulangan Bencana Daerah/ Regional Disaster Management Agency)

BPBD is a government agency in charge of coordinating disaster relief in Bandung Regency.

DASI PENA (Pemuda Siaga Peduli Bencanal Youth Preparedness Disasters Preparedness)

DASI PENA is a volunteer community, composed of Scout, nature lovers and other youths component formed by the Ministry of Health of Republic of Indonesia to support health efforts in disaster management, especially in the emergency response phase.

PMS (Pekerja Sosial Masyarakat/ Social Community Worker)

PSM is a volunteer community which comes from local community, formed by the Ministry of Social Services of Republic of Indonesia

PUSDALOPS (Pusat Pengedali Operasi/ Operations Control Center )

PUSDALOPS is Operations Control Center Manager, is a unit of BPBD

SAR (Search and Rescue)

SIBAT (Relawan Siaga Bencana Berbasis Masyarakat/ Volunteer of Disaster Preparedness based on community)

SIBAT a volunteer community with the members are selected from cadre mover (kader penggerak masyarakat), established by Indonesian Red Cross (PMI) cooperation with the American Red Cross (AMCROSS). Team of SIBAT will run the FIRST program (Integrated Community Based Risk Reduction) which provide benefits to people in the neighborhood.

TAGANA (Taruna Siaga Bencana/ Youth for Disaster-Preparedness)

TAGANA is a volunteer community formed by the Ministry of Social Sevices of the Republic of Indonesia. One of their activities is Village of Disaster Preparedness (Kampung Siaga Bencana/KSB).

UCS (Relawan Unit Cegah Siaga/ Volunteer of Prevent Preparedness Unit)

UCS is a volunteer community formed by the Regional Disaster Management Agency (BPBD). 


\section{Brief Biography of Presenter}

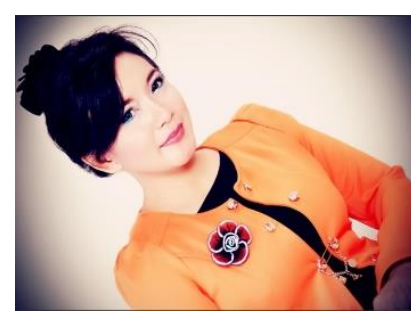

Nuning Kurniasih holds Master degree in Library and Information Science from Univesitas Indonesia. She started her career in 2000 as Lecturer and Researcher at Padjadjaran University (Unpad), Bandung, Indonesia, where she served as Secretary of Public Relations, Head of Computer Laboratory etc and currently is heading the Computer Mediated Communication Laboratory at Faculty of Communication Science. She joined the project on Historical Archive for Human Evolution and Development at Leiden University, Netherlands in 2011. She is representing Indonesia in the Editorial Board of ELIS since 2016, Country Coordinator in International Librarian Network (ILN) in 2014 and Editorial Board of "Journal of "Informatics Studies" since 2014. Her research interest are Information Economics, Social Media, Information Retrieval, Digital and Cultural Literacy, Health Information, Informatics/Altmetrics, Digital Archiving and ICT application for knowledge management. She achieved "The Top Conference Paper Myung-Seok Park Award" from Pacific and Asian Communication Association (PACA) 2014. More about Ning : Www.nuningkurniasih.wix.com/ladangilmu 